\title{
Finansowe i społeczne aspekty prywatyzacji oszczędności emerytalnych
}

\section{FINANCIAL AND SOCIAL ASPECTS PRIVATIZATION OF RETIREMENT SAVINGS}

Prywatyzacja funduszy emerytalnych w Polsce rozpoczęla się w 1999 r., kiedy system zdefiniowanego świadczenia zastapiono systemem zdefiniowanej składki, $w$ nastepnych latach sukcesywnie likwidując niemal wszystkie uprawnienia pracownicze. Podziat składki między OFE a ZUS wygenerowat ogromny (siegajacy $300 \mathrm{mld}$ zt) dtug publiczny, którego obstuga byta rujnująca dla budżetu państwa. Pod presja procedury nadmiernego deficytu, nałożonej na Polske przez Unie Europejska, zainicjowano proces likwidacji tych funduszy, aby poprawić wynik polskiego sektora general government, co zakończyło się powodzeniem, ale prowadziłoby $w$ kilkunastoletniej perspektywie do catkowitej likwidacji OFE. Może temu zapobiec „Plan Budowy Kapitału”, który polega na wzmocnieniu rynku kapitałowego, ale niesie za soba poważne ryzyko zagrożenia ubóstwem $i$ wywłaszczenia osób, które weszły na rynek pracy po $1990 \mathrm{r}$. lub później. Prywatyzacja aktywów OFE przekreśla bowiem szanse na wzmocnienie publicznego systemu zabezpieczenia społecznego, a nowe obciąienia zwiazane z przymusowym tworzeniem kapitałowego filara emerytalnego moga negatywnie wplynać na kondycje i rozwój matych $i$ średnich przedsiębiorstw produkcyjnych i ustugowych, a tym samym znacznie ostabić potencjat realnej sfery polskiej gospodarki.

Słowa kluczowe: otwarte fundusze emerytalne, rynek kapitałowy, pracownicze plany kapitałowe, ryzyka socjalne.

JEL Codes: H55, H75

\section{Wstẹp}

Po załamaniu ustanowionego w Bretton Woods globalnego ładu finansowego, gdy kształtowała się epoka pieniądza w pełni fiducjarnego, powstała potrzeba stworzenia nowego paradygmatu funkcjonowania rynków finansowych, których istotną częścią są ściśle ze sobą powiązane fundusze emerytalne i inwestycyjne. Poligonem doświadczalnym w tej dziedzinie była reforma emerytalna w Chile, przeprowadzona w 1980 roku pod wpływem koncepcji ekonomicznych Miltona Friedmana i jego współpracowników ze Szkoły Chicagowskiej. Ekonomiści tej szkoły nie byli jeszcze skonfrontowani z rzeczywistymi skutkami swoich idei i widzieli w emeryturach kapitałowych rozwiązanie poważnego problemu finansowo-społecznego. W ten sposób, w warunkach rządów autorytarnych sprawowanych przez Augusto Pinocheta, powstały 
chilijskie fundusze emerytalne, dostarczając empirycznego dowodu, że piramidy finansowe można budować pod auspicjami państwa. Doświadczenie to wykorzystano w propagowaniu idei prywatyzacji emerytur $\mathrm{w}$ innych krajach zaliczanych do grupy rynków wschodzących, nie bacząc na długofalowe skutki tej decyzji dla finansów publicznych i bezpieczeństwa emerytów.

Jednym z mitów przemawiających za budową kapitałowego filara emerytalnego była jego rzekomo wysoka efektywność w pomnażaniu oszczędności emerytalnych. Wysoka stopa zwrotu może teoretycznie występować ponieważ filar ten sam stwarza sobie zapotrzebowanie na papiery wartościowe $i$ wszystko pnie się do góry, ale gdy zapotrzebowanie na papiery wartościowe spadnie do normalnego poziomu, wynikajacego ze zmiany pokoleń, zabraknie środków na pokrycie zobowiazań wobec świadczeniobiorców, [a w przypadku gdy jest to ich główne bądź jedyne źródło utrzymania - przyp. aut.] pozostanq oni bez środków do życia (Łaski, 2003, s. 83). Jeżeli wiadomo, że tak jest, to dlaczego - pomimo wielu negatywnych doświadczeń - wciąż powraca w Polsce idea częściowej, teoretycznie dobrowolnej, ale w praktyce przymusowej prywatyzacji emerytur pracowniczych?

Celem niniejszego artykułu jest wskazanie zagrożeń socjalnych, jakie niesie polskim emerytom system zdefiniowanej składki, wspomagany obarczonymi wysokim ryzykiem produktami oferowanymi przez instytucje rynku kapitałowego.

\section{Przesłanki prywatyzacji emerytur}

Pod koniec lat 80., Departament Skarbu wraz z Departamentem Handlu rządu federalnego USA zawarły porozumienie $\mathrm{z}$ Zarządem Rezerwy Federalnej, Międzynarodowym Funduszem Walutowym oraz Bankiem Światowym (tzw. Konsensus Waszyngtoński) w celu wzmocnienia wpływów transnarodowych korporacji finansowych $\mathrm{w}$ krajach o słabej walucie, $\mathrm{z}$ deklarowaną intencją wzmocnienia równowagi monetarnej $\mathrm{w}$ tych krajach, $\mathrm{w}$ oparciu o koncepcje Miltona Friedmana (Williamson, 2004, s. 2-3 i 593). Jednym z głównych filarów tego projektu była liberalizacja i deregulacja gospodarki, powiązana z redukcją pracowniczych uprawnień socjalnych i prywatyzacją emerytur na wzór „reformy” systemu emerytalnego w Chile, której wady jeszcze się wtedy nie ujawniły.

Faktycznym celem pełnego lub częściowego przejścia na system emerytur kapitałowych jest w rzeczywistości wsparcie instytucjonalnych inwestorów giełdowych (wielkich banków inwestycyjnych oraz powiązanych $\mathrm{z}$ nimi funduszy wysokiego ryzyka), ale fakt ten nie dotarł ani wówczas ani obecnie nie dociera do powszechnej świadomości. Ten segment rynku finansowego wybrano, mając na uwadze fakt, że ubezpieczenia emerytalne są z reguły ubezpieczeniami zdefiniowanej daty, toteż przez dziesięciolecia generują dochody firm inwestycyjnych, nie pociągając za sobą konieczności masowej wypłaty świadczeń. Ponadto, prywatyzacji emerytur z reguły towarzyszą drastyczne cięcia wydatków socjalnych, co - jak pisał Friedman w liście do Augusto Pinocheta - przyspiesza rozwój rynku kapitałowego, który bardzo ułatwi przechodzenie przedsiębiorstw i przedsięwzięć znajdujących się wciąż jeszcze w rękach państwa w ręce prywatnych inwestorów (cyt. za Klein, 2010). 
$\mathrm{Na}$ początku lat 90. minionego wieku, zasadnicze elementy chilijskiego systemu emerytalnego, zostały zastosowane do budowy kapitałowego filara emerytalnego w innych krajach z grupy rynków wschodzących, a w szczególności w krajach Europy Środkowej i Wschodniej, natomiast kraje Europy zachodniej zdecydowanie odrzuciły ten model ochrony ryzyka starości.

Od czasu upowszechnienia praktyki systematycznego zasilania prywatnego sektora finansowego funduszami emerytalnymi w Stanach Zjednoczonych, Japonii oraz w niektórych innych krajach azjatyckich, globalny rynek finansowy rozwija się nieporównanie szybciej od realnej gospodarki, generując coraz wyższe zagrożenie kryzysami. Wykazuje przy tym nieporównanie większą odporność na generowane przez siebie szoki, głównie dzięki hojnej, rządowej pomocy kapitałowej dla wielkich korporacji finansowych, kosztem wzrostu zadłużenia sektora rządowego i spowolnienia procesu odrabiania strat $\mathrm{w}$ sektorze niefinansowym. Potwierdza to statystyka. W roku 1980 aktywa instytucji finansowych stanowiły 113\% globalnego PKB, w roku 2007 wskaźnik ten wzrósł do 360\%, aby dwa lata później, po ujawnieniu toksycznych właściwości niektórych finansowych produktów strukturyzowanych, obniżyć się do $250 \%$. Jednak już w roku 2013 odbudowane aktywa instytucji finansowych stanowiły aż 360\% globalnego PKB (odpowiednio 275 bln USD wobec 77 bln USD), koncentrując się głównie na tzw. dojrzałych rynkach finansowych krajów OECD. Według aktualnie dostępnych danych, w roku 2015 aktywa instytucji finansowych mających centralę w jednym z 28 takich krajów wzrosły do 321 bln USD, co stanowiło równowartość 430\% PKB wytworzonego w tych krajach; w Holandii i innych małych krajach zachodnioeuropejskich relacja ta sięgała nawet ok. 700\% (World Bank, 2019).

Mamy gigantyczny przemyst finansowy, który działa na zasadzie: gdy wygram, korzystam ja, gdy przegram traci ktoś inny, toteż [przemysł ten] zdołał zubożyć nas wszystkich ciagnąc z tego pokaźne zyski (Krugman, 2012). W świecie finansów nie ma dziś żadnych hamulców, żadnej wstrzemięźliwości. Rządzi chciwość (Kobosko, 2012), a wysoki stopień nasycenia produktami finansowymi macierzystych rynków skłania wielkie korporacje do rabunkowej penetracji rynków wschodzących, skąd do $2030 \mathrm{r}$. zamierzają pozyskać ok. 30 bln USD, sprzedając kapitałowe programy emerytalne, odwróconą hipotekę oraz inne instrumenty finansowe obarczone - po stronie nabywcy wysokim ryzykiem (McKinsey, 2012). Strategię tę wspierają wszyscy sygnatariusze Konsensusu Waszyngtońskiego, powołujący się m.in. na alarmistyczny raport Banku Światowego Averting the Old Age Crisis (1994). Raport ten ma charakter naukowolobbystycznej argumentacji na rzecz zastępowania państwowych systemów emerytalnych, z pozoru bardziej efektywnymi prywatnymi planami emerytalnymi. Wykorzystano w nim alarmistyczne prognozy demograficzne dla udowodnienia tezy o rzekomej niewydolności publicznych systemów emerytalnych w warunkach starzejących się społeczności Europy. W rzeczywistości, stabilność tych systemów zależy głównie od sytuacji na rynku pracy, w szczególności od poziomu wynagrodzeń i powszechności ubezpieczeń społecznych, a tylko w niewielkim stopniu od ogólnej liczby mieszkańców i zmieniającej się (stosunkowo powoli, choć systematycznie) struktury demograficznej w większości krajów rozwiniętych gospodarczo. Jednakże, abstrahowanie od sytuacji na rynku pracy i powoływanie się na obiektywnie niekorzystne trendy demograficzne jest użytecznym narzędziem propagowania idei 
prywatyzacji systemów emerytalnych, toteż środowiska powiązane biznesowo i towarzysko z rynkiem kapitałowym uporczywie trzymają się tej argumentacji, nie zważając na negatywne społeczne i finansowe konsekwencje prywatyzacji emerytur. Środowisko to wszelkimi dostępnymi metodami uparcie dąży do marginalizacji powszechnego, państwowego systemu ubezpieczeń pracowniczych, tylko po to aby wzmocnić kontrolowaną przez siebie giełdę i rynek komercyjnych papierów wartościowych.

Od czasu opublikowania raportu Banku Światowego na temat związków między demografią a bezpieczeństwem socjalnym emerytów minęło 25 lat, można więc było naocznie przekonać się, że wymuszanie totalnej prywatyzacji [emerytur - przyp. aut.] to ekonomiczny absurd, którego jedynym celem jest przesunięcie kolejnych dziedzin życia ze sfery publicznej, podlegajacej demokratycznej kontroli, w prywatne ręce (Chomsky, 2004).

\section{Mityczny rynek finansowy wobec wyzwań rozwojowych realnej gospodarki}

Silny rynek kapitałowy jest niezbędny dla budowy silnych fundamentów gospodarki, podwyższania potencjatu wzrostu dochodów indywidualnych i PKB, co dtugoterminowo sprzyja wzmocnieniu stabilności systemu emerytalnego oraz wzrostowi świadczeń emerytalnych. Tekst ten pochodzi z uzasadnienia do projektu ustawy z 27 maja 2019 r. o zmianie niektórych ustaw w związku z przeniesieniem środków z otwartych funduszy emerytalnych (OFE) na indywidualne konta emerytalne (IKE). Jest ewidentnym przykładem wpływu lobby reprezentującego interesy inwestorów z rynku kapitałowego na polityków, bowiem kluczowym beneficjentem zapowiedzianych zmian będa jednak instytucje działające na rynku finansowym (Oręziak, 2019), w szczególności zaś instytucjonalni oraz profesjonalni inwestorzy giełdowi, ale nie emeryci.

Bezpośredni związek między kapitalizacją spółek i ich wartością realną istniał pół wieku temu, ale obecnie w sensie absolutnym w ogóle już nie istnieje, a wybiórcze, nadmuchiwanie przez spekulantów poszczególnych sektorów giełdowych, a nawet windowanie notowań akcji pojedynczych spółek, niszczy kapitalizację spółek giełdowych jako miernik ich względnej wartości. Innymi słowy: wartość rynkowa w ogóle nie odzwierciedla rzeczywistej wartości spółki. W warunkach współczesnych, giełda papierów wartościowych może swymi rozmiarami przekraczać potencjał wytwórczy realnej gospodarki ${ }^{1}$, ale od dawna przestała być miejscem pozyskiwania kapitału na inwestycje produkcyjne. Ten fakt przemilcza się, bo przez kilkadziesiąt ostatnich lat szkoły biznesu, świątynie kształcenia kadr biznesowych, powtarzały mantre mówiąca, że kurs giełdowy $i$ wyniki finansowe powinny stanowić nadrzędny interes danego przedsiębiorstwa (Dembinsky, 2012, s. 146). Logika tej prostej idei była (...) przedstawiana jako wynikająca z nauk ścistych, toteż stała się baza kształcenia wielu pokoleń menedżerów. Jej wdrożenie do praktyki prowadzi do obsesji efektywności

\footnotetext{
${ }^{1}$ Przyjmując jako miernik roli giełdy w gospodarce danego kraju relację między kapitalizacją spółek giełdowych a PKB można zauważyć, że spośród krajów OECD tylko w Stanach Zjednoczonych, Japonii i we Francji poziom tego wskaźnika przekraczał 100\%. W 2017 r. (według danych Banku Światowego) wyniósł on w USA $164,8 \%$, w Japonii - 127,7\%, w strefie euro kształtował się na poziomie 77,6\% (w tym we Francji 106,5\%, ale w Niemczech tylko 61,3\%), w Polsce - 38,2\%, a na Węgrzech - 22,6\% (World Bank, 2019).
} 
finansowej [która] deprawuje kierownictwo, a tym samym staje się źródtem wyzysku, który ostabia nie tylko przedsiębiorstwa, ale cata tkankę społeczna, a także instytucje publiczne (Sumatra, 2005, s. 75).

W dużych przedsiębiorstwach nakłady na środki trwałe pochodzą przede wszystkim ze środków własnych, w następnej kolejności z instrumentów dłużnych, uporządkowanych według rosnącego ryzyka (Myers, Mayful 1984, s. 187-222; Myers 1984, s. 574-592). Ten model finansowania rozwoju realnej sfery gospodarki powoduje, że spótki, które normalnie pożyczaty oszczędności innych, aby je zainwestować, same stały się bardzo oszczędne. Nawet te, które ciesza się wysokimi zyskami i plynnościa, zamiast rozwijać swój biznes poprzez inwestycje, rozbudowuja swoje skarbce, ograniczając własne zadtużenie i odkupując własne akcje (IMF, 2006, s. 107). Opóźnia to tempo wdrażania innowacji, hamując postęp techniczny i wzrost wydajności pracy, skłania natomiast do rozpraszania działalności przedsiębiorstw w celu ograniczania ryzyka i maksymalizacji krótkookresowej stopy zysku.

European Investment Bank (EIB) przeprowadził w 2016 roku, na reprezentatywnej próbie 12500 niefinansowych przedsiębiorstw z całej Europy (w tym 479 z Polski), badanie źródeł finansowania inwestycji ${ }^{2}$. Wyniki tego badania potwierdzają, żew większości krajów europejskich już istniejące przedsiębiorstwa finansowały inwestycje przede wszystkim ze źródeł wewnętrznych. W Polsce udział środków własnych w finansowaniu inwestycji wynosił ok. $65 \%$, podobnie jak w Czechach, Niemczech, czy na Litwie, a przeciętnie w Unii Europejskiej - ok. 60\%. Z badania tego wynika również, że dominującą formą finansowania zewnętrznego inwestycji był kredyt bankowy; w Polsce jego udział wynosił ponad $15 \%$, w całej UE ok. $25 \%$. Ważną rolę w finansowaniu inwestycji ze źródeł zewnętrznych odgrywał leasing, którego udział wyniósł w Polsce ok. 8\%, a średnio w Unii Europejskiej ok. 8-9\%. Resztę stanowiły niemal w całości subwencje i dotacje dla przedsiębiorstw w ramach pomocy publicznej. Natomiast skala finansowania inwestycji za pomocą nowo wyemitowanych akcji była marginalna; w Polsce ich udział wyniósł $0,37 \%$ nakładów na środki trwałe brutto, a w całej badanej zbiorowości przedsiębiorstw funkcjonujących na obszarze Unii Europejskiej $-0,43 \%$.

Emisja akcji to ryzykowna, a nierzadko także skomplikowana i kosztowna forma pozyskiwania kapitału, wiążąca się z dodatkowymi obowiązkami informacyjnymi. Należy także dodać, że nowa emisja często prowadzi do zmian w strukturze właścicielskiej spółki i do wzrostu liczby akcjonariuszy, którzy będą uczestniczyli $\mathrm{w}$ podziale potencjalnych zysków $\mathrm{z}$ inwestycji, co powoduje spadek zysku przypadającego na jedną akcję. Nowa emisja akcji może być też negatywnie interpretowana przez rynek jako oznaka problemów z płynnością finansową w przedsiębiorstwie lub sygnał wysokiego ryzyka danej inwestycji, a w konsekwencji będzie prowadzić do spadku cen już wcześniej wyemitowanych akcji. Z powyższych powodów rola nowych emisji w finansowaniu rozwoju przedsiębiorstw jest tak bardzo ograniczona.

Giełda przestała więc być miejscem pozyskiwania kapitału na rozwój realnej sfery gospodarki; przeciwnie, pogoń za stałym podnoszeniem bieżącej wartości rynkowej

\footnotetext{
${ }^{2}$ Pytanie brzmiało „Approximately what proportion of your investment in the last financial year was financed by each of the following?".
} 
spółek ogranicza długoterminowe inwestycje, hamuje innowacje tylko po to, aby kadra menedżerska mogła dobrze wypaść w sprawozdaniach kwartalnych oraz rocznych rozliczeniach wyniku finansowego, od którego uzależnione są jej wynagrodzenia (Barton D., Wiseman M., 2014). Krótkowzroczna, oportunistyczna strategia menedżerów spółek giełdowych jest zarzewiem wielu kryzysów, jakie dotknęły światową gospodarkę w wieku XX i w bieżącym stuleciu. Również w Polsce nadzieja na wysokie stopy zwrotu $\mathrm{z}$ kapitału zachęca do stosowania różnego typu dźwigni finansowych i angażowania kapitału w transakcje o wysokim ryzyku, czego w swoim czasie boleśnie doświadczyli m.in. przedsiębiorcy zawierający niesymetryczne umowy na opcje walutowe. Ponadto, w Polsce, podobnie jak w innych krajach z grupy rynków wschodzących, gdzie zagraniczne inwestycje portfelowe odgrywają istotną rolę, giełda ułatwia drenaż kapitału i jego wywóz za granicę ${ }^{3}$.

W początkach transformacji ustrojowej polski rynek kapitałowy był tworzony od zera. Reaktywowana (po ponad pięćdziesięciu latach) w kwietniu 1991 r. warszawska giełda papierów wartościowych stała się przede wszystkim platformą ułatwiającą wyprzedaż majątku narodowego, na czym korzystali tylko nieliczni wtajemniczeni. Obecnie instytucja ta, ze względów oczywistych, jest zdominowana liczebnie przez polskie spółki, ale w kapitalizacji dorównuje im niewielka grupa spółek zagranicznych (wykres 1). Jest to rzeczą naturalną; kapitał zagraniczny z zasady przejmuje tylko wielkie spółki kontrolujące znaczną część rynku w realnej gospodarce, bo (za wyjątkiem wrogich przejęć, mających na celu ograniczenie bądź wyeliminowanie konkurencji) koszty zarzadzania i kontroli małych firm są proporcjonalnie zbyt wysokie w stosunku do spodziewanych korzyści.

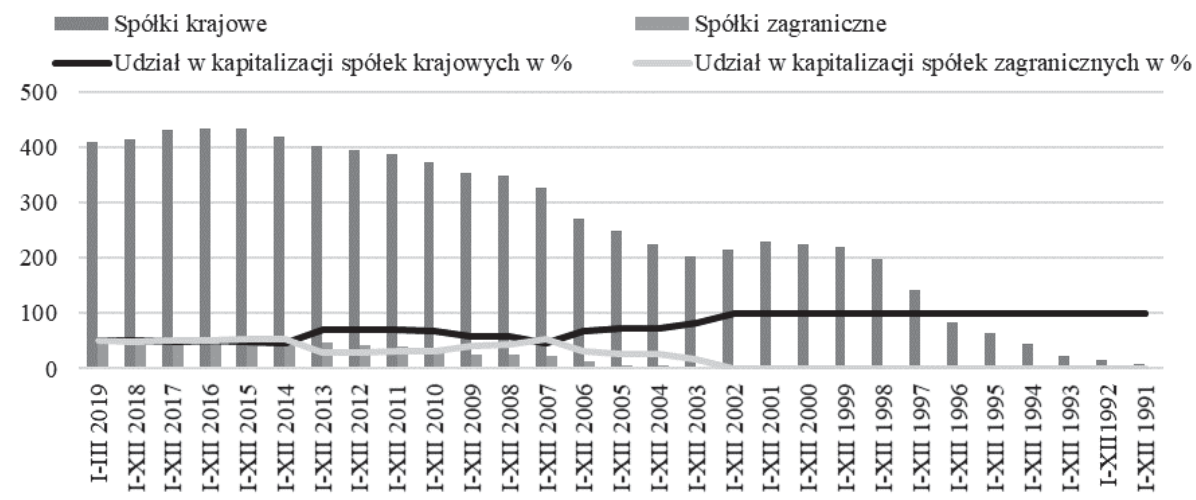

Wykres 1. Spółki notowane na GPW wg kryterium rezydenta Źródło: GPW

Od 2016 roku, kiedy praktycznie nie ma już co prywatyzować, liczba wycofań przewyższa liczbę debiutów (wykres 2), a indeksy giełdowe nie rokują wysokich stóp

\footnotetext{
${ }^{3}$ W 2018 r. wykazane w bilansie płatniczym transfery (rozchody) z tytułu inwestycji portfelowych w Polsce wyniosły 16,4 mld zł, a dywidendy (rozchody) z tytułu inwestycji bezpośrednich 40,3 mld zł. Saldo dochodów, zarówno z inwestycji portfelowych jak i bezpośrednich było ujemne; odpowiednio: 14,3 mld zł i 72,3 mld zł (NBP 2019, s. 58).
} 
zwrotu z inwestycji portfelowych. W debacie, jaka odbyła się trzy lata później na temat perspektyw rozwoju rynku kapitałowego w Polsce, inwestorzy ocenili kondycję warszawskiej giełdy na 2-3 punkty w skali sześciopunktowej (Pernet M., 2019), wyrażając równocześnie nadzieję na poprawę koniunktury za sprawą przekształcenia otwartych funduszy emerytalnych (OFE) w specjalistyczne fundusze inwestycyjne otwarte (SFIO) oraz wejścia w życie ustawy o pracowniczych planach kapitałowych (PPK). Oszacowano, że po tej operacji zaangażowanie oszczędności polskich gospodarstw domowych na rynku kapitałowym zwiększy się z ok. 170 mld zł do ok. 500 mld zł w perspektywie $2027 \mathrm{r}$.

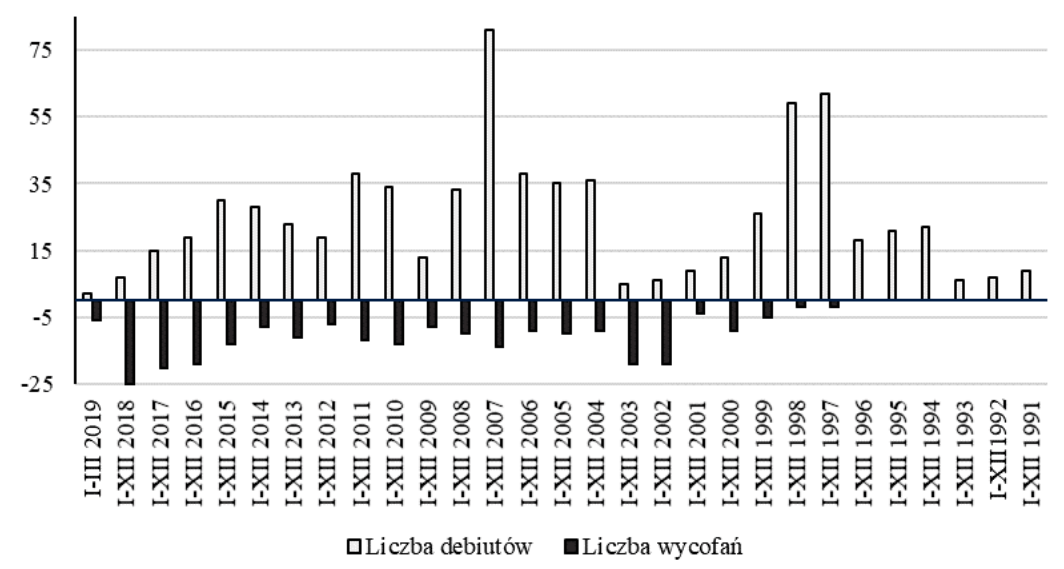

Wykres 2. Liczba debiutów i wycofań spółek z rynku głównego GPW Źródło: GPW

Istotnym celem SFIO i PPK jest więc przekierowanie funduszy pobranych z dochodów pracowników, pracodawców i budżetu państwa na giełdę, celem sfinansowania wzrostu indeksów (poprawy kondycji i koniunktury GPW), a nie poprawa położenia emerytów, którzy poniosą w całości ryzyko nietrafionych spekulacji, czego empirycznym dowodem są wyniki OFE.

\section{OFE - piramidalna katastrofa emerytalna}

Dożycie wieku emerytalnego jest jednym z dziewięciu ryzyk socjalnych wymienionych w konwencji 102 Międzynarodowej Organizacji Pracy i podlegających w krajach Unii Europejskiej obowiązkowej ochronie państwa. Emerytura jest świadczeniem zabezpieczającym byt człowieka, który czerpie środki utrzymania $z$ zatrudnienia lub innej działalności $i$ dla którego zaprzestanie zatrudnienia (działalności) ze względu na wiek oznacza brak dochodu z pracy, także dochodu odtożonego (zaoszczędzonego, kapitalizowanego), bo kalkulacja płacy (przychodu) opiera się na zatożeniu, że okres starości zostanie objęty jaką́ forma zabezpieczenia spolecznego. (...) W aspekcie gwarancyjnym ubezpieczenie emerytalne, jako regularna ochrona tego ryzyka trwa najdlużej od podjęcia pierwszego zatrudnienia lub innej działalności (Jończyk, 2001, s. 14-15). Inflacja, zmiana struktury cen i zmiana modelu konsumpcji powodują, że prawie nikt nie jest w stanie w okresie aktywności zawodowej 
zaoszczędzić tyle, żeby po osiągnięciu wieku emerytalnego utrzymać się przez 20 i więcej lat. Nawet gdyby pracownik odkładał większość tego co zarobi, nie zdoła zabezpieczyć sobie bytu na starość, bo siła nabywcza zgromadzonych oszczędności obniża się wraz z upływem czasu pod wpływem różnych czynników, niekiedy w sposób gwałtowny i nieprzewidywalny. Emerytura nie jest jałmużną, ale rekompensatą za wiele lat opłacania składek $\mathrm{i}$ pracy na rzecz całego społeczeństwa, toteż $\mathrm{w}$ kalkulacji wysokości tego świadczenia powinien być stosowany algorytm, który daje gwarancje godziwej stopy zastąpienia wynagrodzenia świadczeniem emerytalnym.

Reforma systemowa z 1998 r. likwidująca klasyczny system emerytalny na rzecz systemu zdefiniowanej składki jest sprzeczna z definicją i funkcją emerytury. Koncepcja przekształcenia systemu emerytalnego z tak zwanego repartycyjnego, jakim jest ZUS, w kapitałowy, oparta była na zawierzeniu iluzorycznej nadziei $w$,wiecznie rosnacy rynek kapitałowy”, a faktycznie na niezrozumieniu elementarnych kwestii ekonomicznych (Żyżyński, 2013). Świadczenie, które otrzymują polscy emeryci objęci systemem zdefiniowanej składki, to w istocie dochód rentierski, którego źródłem jest zwaloryzowany kapitał początkowy i wpłacone (waloryzowane i/lub indeksowane) składki emerytalne. Taki system ochrony ryzyka starości przeczy istocie klasycznej emerytury, która nie jest i nie powinna być dochodem z (obarczonej wysokim ryzykiem) inwestycji kapitałowej.

Klasyczna emerytura powinna składać się z części osłonowej (zależnej od kosztów utrzymania i potencjału gospodarki narodowej) oraz osobistego wkładu pracownika do funduszu emerytalnego, zależnego od jego stażu pracy i zgromadzonych (waloryzowanych i/lub indeksowanych) oszczędności emerytalnych. Jej uzupełnieniem mogą być komercyjne produkty emerytalne, dobrowolnie nabywane na własne ryzyko przyszłego emeryta, na które - jak wskazuje doświadczenie - efektywny popyt wzrasta wraz z podnoszeniem się poziomu zamożności społeczeństwa; według szacunków Alliance, dopiero dochód rozporządzalny netto na jednego mieszkańca rzędu ok. 45-50 tys. USD rocznie umożliwia indywidualne inwestowanie w takie produkty. Dochody większości Polaków były i jeszcze długo będą znacznie niższe, toteż pierwszy etap prywatyzacji emerytur w Polsce wymagał transferu znacznej części składek emerytalnych zasilających Fundusz Ubezpieczeń Społecznych (zarządzany przez ZUS) do nowo powstałych firm inwestycyjnych (Powszechnych Towarzystw Emerytalnych PTE, zarządzających OFE).

Prywatyzując emerytury pracownicze, świadomie lub nieświadomie utworzono swoisty trójkąt bermudzki, którego wierzchołkami były: Ministerstwo Finansów, Zakład Ubezpieczeń Społecznych i PTE wraz z OFE. Łącznie w latach 1999-2019 przekazano z ZUS do OFE składki emerytalne w kwocie ok. 216 mld zł, co w rachunku ciągnionym (wykres 1) - uwzględniającym obsługę długu wygenerowanego przez te fundusze kosztowało polskich podatników grubo ponad $300 \mathrm{mld}$ zł. Powstałe w wyniku tych transferów niedobory w emerytalnym systemie państwowym uzupełniano bowiem dotacjami rządowymi dla ZUS, które - w sytuacji utrzymującego się od $1991 \mathrm{r}$. deficytu budżetowego - powodowały niebezpiecznie szybkie narastanie zadłużenia skarbu państwa, a w konsekwencji coraz wyższe potrzeby pożyczkowe Ministra Finansów i wzrost kosztów odsetkowych obsługi tego długu. Licząc się z konsekwencjami budowy kapitałowego filara emerytalnego, starano się nie dopuścić do przekroczenia konstytucyjnych norm ostrożnościowych, przenosząc na emerytów konsekwencje tej 
decyzji i spowalniając proces zadłużania państwa poprzez ograniczanie wydatków budżetowych, zwłaszcza na cele zdrowotne, edukację i pomoc społeczną.

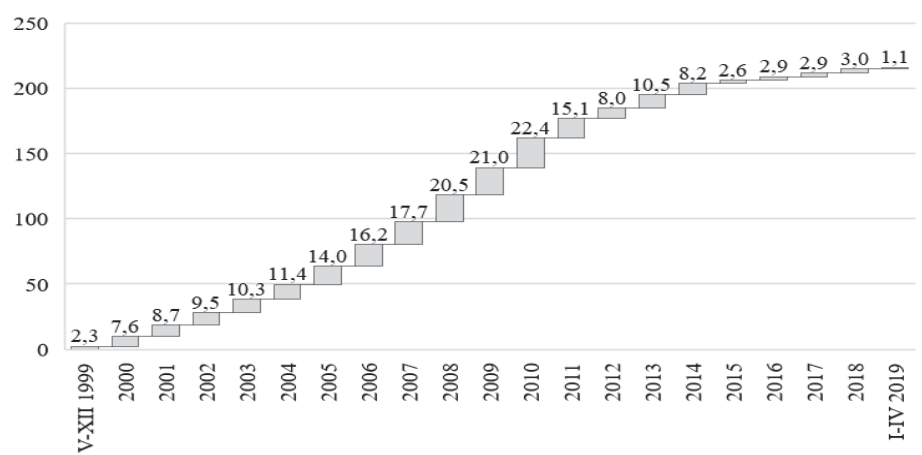

Wykres 3. Skumulowana roczna skladka przekazana przez ZUS do OFE, w mld zl

Źródło: ZUS (2019), https://www.zus.pl/o-zus/o-nas/finanse/przekazywanie-skladek-do-ofe/2019//info/2578597

Już w momencie wdrażania reformy systemu ubezpieczeń społecznych (1998 r.) ustawowo zmieniono algorytm obliczania emerytury na niekorzyść świadczeniobiorców urodzonych po 31 grudnia 1948 r. Potem, pod różnymi pretekstami forsowano zmiany ustawowe, odbierające nabyte już uprawnienia emerytalne młodszym rocznikom. Oszczędności $\mathrm{z}$ tego tytułu (niewspółmiernie małe w stosunku do kosztów utrzymywania OFE) nie zahamowały tempa narastania deficytu i długu sektora rządowego (general government). Wprawdzie, w założeniach reformy emerytalnej przyjęto, że potrzeby pożyczkowe generowane przez transfery składki emerytalnej będą rekompensować przychody $\mathrm{z}$ prywatyzacji przedsiębiorstw państwowych, ale w rzeczywistości, przychody te były niewielkie i mimo ograniczeń ustawowych (do 5\%), przekazywane w lwiej części na Fundusz Reprywatyzacji.

Permanentny, pogłębiający się deficyt sektora general government spowodował, że Polska znalazła się dwukrotnie (w latach 2006 i 2009) pod unijną procedurą nadmiernego deficytu. Starania o uznanie przez Komisję Europejską portfela OFE za integralną część aktywów polskiego sektora finansów publicznych zakończyły się niepowodzeniem (Kempa 2010). W tej sytuacji, gabinet Donalda Tuska przedłożył Sejmowi, a ten uchwalił w 2011 r. ustawę o ograniczeniu na dwa lata partycypacji OFE w składce emerytalnej z 7,3\% do 2,3\%; od 2013 r. Udział OFE w składce emerytalnej ponownie miał rosnąć, osiągając w 2017 r. wielkość docelową 3,5\%. Reforma ta nie doprowadziła jednak do utrzymania na poziomie referencyjnym deficytu i długu sektora instytucji rządowych i samorządowych, więc zdecydowano się na rozwiązanie radykalnie odciążające budżet państwa od wypłat odsetek za obligacje skarbowe w portfelu OFE. Na podstawie ustawy z 6 grudnia 2013 r., w marcu 2014 r. przekazano do ZUS 51,5\% aktywów OFE, księgując równocześnie równowartość zgromadzonych jednostek rozrachunkowych na indywidualnych subkontach pracowniczych. Wartość nominalna przekazanych do ZUS papierów wartościowych wyniosła łącznie 146,0 mld zł, z tego: 130,2 mld zł stanowiły obligacje skarbowe, 15,6 mld zł obligacje Banku Gospodarstwa Krajowego, a resztę inne papiery wartościowe gwarantowane przez Skarb 
Państwa (252 mln zł) i gotówka (1862 mln zł). Wszystko to (wbrew obiegowym i krzywdzącym opiniom pojawiającym się do dziś dnia w różnych mediach) ${ }^{4}$ odbyło się z poszanowaniem majątkowych praw uczestników OFE; nikt z oszczędzających nic nie stracił na tej operacji. Zniesiono przy tym przymus członkostwa w OFE, tak że liczba członków tych funduszy zmniejszyła się z ok. 16 mln do niespełna miliona w 2014 r. i pozostała na tym poziomie, zaś dotacje budżetowe na wyrównanie ubytku składki w ZUS spadły do ok. 3,0 mld zł.

Oprócz doraźnych korzyści, wynikających z ograniczenia liczby członków i znacznie mniejszych dotacji na wyrównanie ubytku składki w ZUS, reforma OFE zapewniła względnie trwałą poprawę wyniku sektora general government (wykres 4).

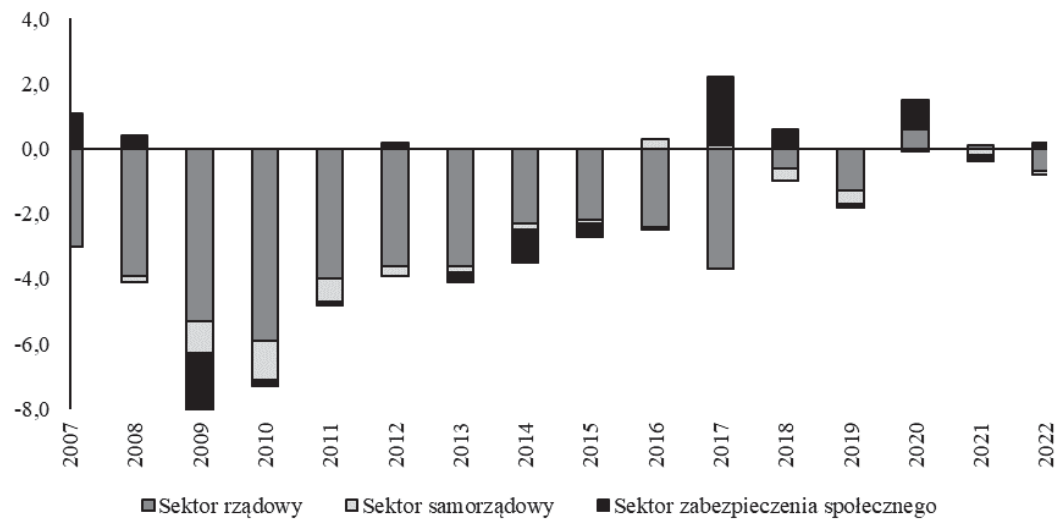

Wykres 4. Rzeczywisty i prognozowany na lata 2019-2022 wynik sektora general government jako \% PKB

Źródło: opracowanie na podstawie danych GUS dot. notyfikacji fiskalnej oraz danych MF (2019, s. 39).

Nie pomniejszając znaczenia podjętych i realizowanych inicjatyw dotyczących dyscypliny finansów publicznych i uszczelnienia systemu podatkowego, należy stwierdzić, że przejęcie części obligacyjnej portfela OFE ułatwiło w latach 2016-2019 sfinansowanie kosztownych programów wspierających polskie rodziny. Nadal jednak nie znaleziono właściwego rozwiązania dla poprawy położenia materialnego milionów polskich emerytów, pomimo złych doświadczeń z przeszłości i alarmistycznych prognoz stopy zastąpienia ostatniego wynagrodzenia emeryturą (tabela 1). Relacja wysokości pierwszej przyznanej emerytury do średniego miesięcznego wynagrodzenia w ostatnim roku aktywności zawodowej (czyli stopa zastąpienia), która dla osób urodzonych przed 1 stycznia 1949 r. przed reformą systemową wynosiła ok. 70\%, obniżyła się w 2018 r. do $56,4 \%$. W ostatnim kwartale minionego roku wskaźnik ten był jeszcze niższy $(53,3 \%)$ i będzie nadal spadał $\mathrm{w}$ tempie ok. $1 \%$ rocznie, w miarę obniżania udziału kapitału emerytalnego w ogólnej kwocie oszczędności emerytalnych.

\footnotetext{
${ }^{4}$ Najwyższa Izba Kontroli w 2014 r. zbadała dokładnie reformę OFE i doszła do wniosku, że gdyby jej zaniechano, to Polska w 2015 r. przekroczyłaby konstytucyjny próg zadłużenia, co przełożyłoby się na wielkość dotacji z budżetu do FUS i wymagałoby obniżenia emerytur, i tak bardzo niskich w stosunku do kosztów utrzymania.
} 
Tabela 1. Udział skladki emerytalnej w wynagrodzeniu i prognozowana przez OECD na rok 2060 stopa zastąpienia wynagrodzenia emeryturą, w \%

\begin{tabular}{|c|c|c|}
\hline Nazwa kraju & $\begin{array}{c}\text { Udział składki emerytalnej } \\
\text { w wynagrodzeniu }\end{array}$ & $\begin{array}{c}\text { Stopa zastąpienia ostatniego } \\
\text { wynagrodzenia emeryturą }\end{array}$ \\
\hline Holandia & 20,9 & 96,9 \\
\hline Dania & 12,8 & 86,4 \\
\hline Włochy & 33,0 & 83,1 \\
\hline Austria & 22,8 & 78,4 \\
\hline Luksemburg & 16,0 & 76,7 \\
\hline Portugalia & 20,2 & 74,0 \\
\hline Hiszpania & 28,3 & 72,3 \\
\hline Irlandia & 14,8 & 72,1 \\
\hline Bułgaria & 17,8 & 69,0 \\
\hline Islandia & 19,4 & 69,0 \\
\hline Słowacja & 18,0 & 63,4 \\
\hline Cypr & 15,6 & 63,4 \\
\hline Belgia & 16,4 & 60,8 \\
\hline Francja & 25,4 & 60,5 \\
\hline Węgry & 30,8 & 58,7 \\
\hline Finlandia & 25,2 & 56,6 \\
\hline Szwecja & 22,9 & 55,8 \\
\hline Litwa & 26,3 & 54,1 \\
\hline Grecja & 20,0 & 53,7 \\
\hline Wielka Brytania & 25,8 & 52,2 \\
\hline Niemcy & 18,7 & 50,9 \\
\hline Estonia & 22,0 & 49,7 \\
\hline Chorwacja & 20,0 & 47,5 \\
\hline Łotwa & 20,0 & 47,5 \\
\hline Republika Czeska & 28,0 & 45,8 \\
\hline Norwegia & 22,3 & 45,1 \\
\hline Szwajcaria & 16,2 & 42,1 \\
\hline Słowenia & 24,4 & 38,1 \\
\hline Rumunia & 26,3 & 36,6 \\
\hline Malta & 20,0 & 33,7 \\
\hline Polska & 19,5 & 31,6 \\
\hline
\end{tabular}

Uwaga: prognozowana stopa zastąpienia emeryturą ostatniego wynagrodzenia została obliczona przy założeniu stałego i pełnego zatrudnienia do osiągnięcia wieku emerytalnego osoby, która rozpoczęła staż ubezpieczeniowy z dniem 1 stycznia 2016 r., otrzymując w całym okresie aktywności zawodowej płacę równą przeciętnemu wynagrodzeniu $\mathrm{W}$ gospodarce narodowej danego kraju. W obliczeniu stopy zastąpienia uwzględniono zarówno emerytury w systemie publicznym jak i z rynku kapitałowego.

Źródło: OECD Pensions Outlook 2018, https://read.oecd-ilibrary.org/finance-and-investment/oecd-pensionsoutlook-2018_pens_outlook-2018-en\#page21

Od 2020 r. wprowadzono doraźne rozwiązanie jakim jest tzw. trzynasta emerytura (w kwocie równej najniższemu gwarantowanemu świadczeniu) przyznawana wszystkim emerytom oraz czternasta emerytura wypłacana najuboższym, proporcjonalnie do kryterium dochodowego. Nie zmienia to faktu, że przy zbliżonym obciążeniu zarobków składką na fundusz emerytalny, przeciętna emerytura w relacji do przeciętnego wynagrodzenia będzie w Polsce najniższa w całej Europie (według niektórych prognoz w 2060 r. stopa zastąpienia wyniesie niespełna 25\%, a więc mniej niż przewiduje to OECD). Grozi to zapaścią cywilizacyjną i katastrofą humanitarną. 


\section{Program Budowy Kapitału - szansa czy iluzja poprawy bytu emerytów}

„Wieloletni Plan Finansowy Państwa na lata 2020-2022” zawierał m.in. zapowiedź przebudowy modelu funkcjonowania OFE w ramach Programu Budowy Kapitatu, którego celem jest zwiększenie bezpieczeństwa finansowego obywateli przez stworzenie dobrowolnego kapitałowego systemu oszczędzania $w$ Polsce oraz dhugoterminowych produktów inwestycyjnych (MF, 2019, s.75). Brak jakichkolwiek racjonalnych przesłanek, aby sądzić, że emerytura z rynku kapitałowego zrównoważy systemową likwidację osłonowej części emerytury pracowniczej, która dotknęła pokolenie urodzone po 31 grudnia 1948 r. Z danych ZUS wynika, że w 2018 r. okresowa emerytura kapitałowa (głównie z OFE) kształtowała się średnio na poziomie 198,70 zł i otrzymywało ją zaledwie 240,5 tys. osób na ogólną liczbę 5624 tys. emerytów. Emerytura kapitałowa była ponad jedenaście razy niższa od przeciętnej emerytury pracowniczej z Funduszu Ubezpieczeń Społecznych i nie wystarczałaby nawet na najskromniejsze utrzymanie (ZUS, 2019, s. 27). Nic nie wskazuje na to, aby sytuacja ta miała zmienić się w przyszłości. Biorąc pod uwagę wysokość środków zgromadzonych na rachunkach członków OFE (wykres 5), emerytura z tego źródła (przy oczekiwanej długości życia 208 miesięcy) wyniesie brutto najwyżej kilkadziesiąt złotych.

Inne prywatne programy emerytalne (IKE, IKZE) również mogą zapewnić co najwyżej kilkudziesięciozłotowe dodatki do podstawowej emerytury i m.in. dlatego (pomimo ulg podatkowych) nie cieszą się - jak dotąd - większym zainteresowaniem Polaków. Stosunkowo najbardziej korzystne dla oszczędzających są Pracownicze Programy Emerytalne, tworzone $\mathrm{z}$ inicjatywy pracodawcy i na jego koszt, przy ewentualnym współudziale pracowników; mają one jeszcze tę zaletę, że są względnie neutralne dla budżetu państwa, a korzystne dla instytucji rynku kapitałowego i beneficjentów. Jednak środki tam zgromadzone są najczęściej podejmowane jednorazowo przez uczestnika, zazwyczaj po osiągnięciu przez niego 60 lat. Pracownicy o długim stażu w PPE otrzymują jednorazowo spore kwoty, lecz najczęściej przeznaczają je w całości na spełnienie marzeń o własnej działce, na pomoc mieszkaniową dla dzieci, czy nowy samochód. PPE nie mogą zatem być podstawą utrzymania na starość, ani znaczącym stałym dodatkiem do emerytury z ZUS.

Program budowy kapitału, w części dotyczącej formalnej likwidacji OFE i zmiana nazwy tych funduszy na ,specjalistyczne fundusze inwestycyjne otwarte" oznacza $\mathrm{w}$ istocie prywatyzację publicznych zasobów tam zgromadzonych. Zmiana nazwy przywraca możliwość inwestowania składek emerytalnych w obligacje skarbowe (czego po reformie z 2013 r. nie mogły czynić OFE). Jest także pretekstem do likwidacji tzw. suwaka emerytalnego, bowiem zniesiona ma być zasada przekazywania do ZUS oszczędności emerytalnych osób, którym do osiągnięcia wieku emerytalnego brakuje 10 lat; zwiększy to odpowiednio środki na kontach SFIO, ale także obciążenia państwa dotacjami do systemu ubezpieczeń pracowniczych. O tym, że reforma OFE jest czysto werbalna świadczy także tryb $\mathrm{w}$ jakim Powszechne Towarzystwa Emerytalne SA przekształcą się w Towarzystwa Funduszy Inwestycyjnych SA. Te same co dotychczas spółki, działające pod nową nazwą niemal automatyczne (z uwagi na duże obciążenia formalne, obliczone na zniechęcenie osób, które chciałyby zrezygnować z ich usług) przejmą aktywa OFE, rejestrując równowartość jednostek rozrachunkowych swych 
członków na wyodrębnionych indywidualnych kontach emerytalnych w już istniejących lub nowo utworzonych IKE. Od tej operacji będzie pobrana (w dwu ratach) „opłata przekształceniowa" w wysokości $15 \%$ ad walorem, w zamian za zwolnienie w przyszłości emeryta $\mathrm{z}$ podatku od zysków kapitałowych. Alternatywą dla przystąpienia członka OFE do IKE jest bowiem możliwość złożenia przez niego deklaracji o przeniesieniu całości zgromadzonych przez niego oszczędności z OFE do Funduszu Rezerwy Demograficznej. Przy wyborze tej opcji nie ma żadnej opłaty, więc została ona bardzo negatywnie przyjęta przez uczestników rynku kapitałowego i ekspertów pracujących na ich rzecz, ale zapewne niewiele spośród 16 mln osób, które mają rachunki inwestycyjne w OFE skorzysta z tej możliwości, zarówno ze względu na skomplikowane procedury, jak i nieznajomość specyfiki konkretnych produktów finansowych.

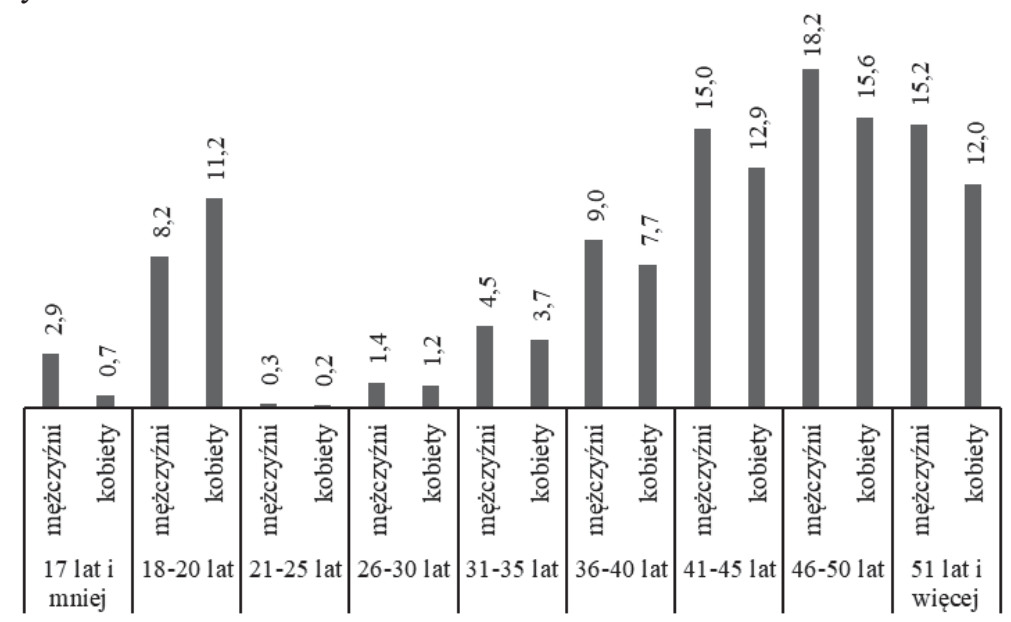

Wykres 5. Średni kapital emerytalny czlonków OFE; stan na 31 marca 2019 r., w tys. zl Źródło: KNF (2019, tabl. 15)

Eksperci rządowi obliczyli, że w latach 2019-2020 do sektora finansów publicznych wpłynie ponad $13 \mathrm{mld}$ zł z tytułu opłaty przekształceniowej, a ponadto powstaną oszczędności (szacowane na 3,5 mld zł rocznie w latach 2020-2022) z tytułu zniesienia transferów na wyrównanie ubytku składek w ZUS dla ok. miliona członków, którzy po reformie 2013 r. potwierdzili chęć kontynuowania członkostwa w OFE. Może wydawać się to niebagatelną sumą $\mathrm{w}$ sytuacji dużego obciążenia budżetu państwa programami socjalnymi, ale gdyby aktywa OFE w całości przekazano na Fundusz Rezerwy Demograficznej zarządzany przez ZUS (lub inny fundusz publiczny), państwo umocniłoby swoje udziały $w$ największych polskich spółkach publicznych, uzyskiwałoby dywidendy i czerpało inne liczne korzyści przez wiele lat. Ten wariant likwidacji OFE byłby jednak sprzeczny $\mathrm{z}$ interesami prywatnych firm sektora finansowego i oczekiwaniami inwestorów giełdowych.

Prywatyzacji miały ulec również aktywa Funduszu Rezerwy Demograficznej, dotychczas usytuowanego w ZUS. Na mocy wprowadzanych zmian środkami FRD zarządzałoby prywatne towarzystwo funduszy inwestycyjnych, którego jedynym akcjonariuszem jest Polski Fundusz Rozwoju SA (nowy ust. 1 w art. 64 ustawy 
o systemie ubezpieczeń społecznych - sus). Zarządzanie środkami FRD będzie odbywać się na podstawie umowy o zarządzanie portfelem, zawieranej $\mathrm{w}$ ramach przepisów ustawy z dnia 27 maja 2004 r. o funduszach inwestycyjnych i zarządzaniu alternatywnymi funduszami inwestycyjnymi, a koszty zarządzania zasobami tego funduszu zostaną sfinansowane z jego środków (do 0,05\% wartości aktywów netto FRD w skali roku). Wynagrodzenia za zarządzanie funduszem inwestycyjnym będą obliczane na każdy dzień wyceny i płatne do 15 . dnia roboczego po zakończeniu miesiąca, za który wynagrodzenie jest należne (nowy ust. 4 i $5 \mathrm{w}$ art. 59 ustawy o sus).

O ile zapowiedź likwidacji OFE wywołała niepokój części środowisk powiązanych z warszawską giełdą papierów wartościowych, o tyle Pracownicze Plany Kapitałowe przyjęto tam entuzjastycznie. W istocie, główna różnica między OFE a SFIO i PPK sprowadza się do tego, że w przypadku otwartych funduszy emerytalnych odpowiedzialność za sfinansowanie tego programu, tj. utrzymanie płynności finansowej ZUS, spoczywała wyłącznie na budżecie państwa, to partycypacja budżetu w budowaniu filara kapitałowego będzie stosunkowo mała, przynajmniej do czasu objęcia systemem PPK całej sfery budżetowej; do SFIO - jak wiadomo - nie przewiduje się żadnych dopłat.

W obecnym kształcie, zasadniczy koszt finansowania PPK został przesunięty na przedsiębiorców (obligatoryjne płatności pracodawcy) oraz pracowników (składki potrącane od wynagrodzeń pracowników). Składka na PPK ma charakter powszechnego para-podatku, toteż układ ten może funkcjonować przez wiele lat, nie rujnując zbytnio finansów publicznych. Ponadto PPK zaprojektowano tak, aby kryzys związany z funkcjonowaniem funduszy emerytalnych odsunąc jak najdalej w czasie; uzyskano to poprzez przeniesienie ryzyka nietrafionych inwestycji na „beneficjentów” tego programu.

Paweł Borys, prezes Polskiego Funduszu Rozwoju otwarcie przyznał, że PPK będą wdrażane z użyciem techniki zalecanej przez ekonomię behawioralną, oddziałującej na podświadomość potencjalnych uczestników: korzystamy z rekomendacji noblisty Richarda Thalera, ekonomisty, który mówi, że budujac takie programy oszczędnościowe, emerytalne, warto dać silniejszy bodziec do tego, by ludzie podejmowali decyzje pozytywna. (...) Musimy ludziom wyttumaczyć, że PPK to zupelnie inny system niż OFE. Co więcej, to reforma, która wyciaga wnioski z blędów przy starcie OFE. I korzysta z najlepszych na świecie doświadczeń zwiazanych z budowa programów emerytalnych, kapitałowych. Dzięki temu programowi będziemy mogli powiedzieć, iż Warszawa jest realnym centrum finansowym Europy Środkowo-Wschodniej (Rzeczpospolita, 2018-0803).

Zmuszając prawnie pracodawców do tworzenia PPK, a pracowników do uczestnictwa w tym programie, przewidziano stosunkowo niewielkie "zachęty” w postaci opłaty powitalnej i premii, a równocześnie wprowadzono niezwykle rygorystyczne sankcje finansowe za ewentualną wcześniejszą rezygnację z uczestnictwa; taki system kar z udziału w PPK jest wzorowany na umowach dotyczących polisolokat, chociaż ów proceder już dawno uznano za oszustwo instytucjonalne. Na tym nie kończą się manipulacje zakodowane $\mathrm{w}$ programie PPK, przewidziano bowiem automatyczne odnowienie udziału pracownika w PPK, który już wcześniej z udziału w tym programie zrezygnował. Wielu uczestników może nie zdawać sobie sprawy, że ponownie zapisano 
ich do PPK; inni natomiast, widząc, że muszą ponawiać skomplikowaną procedurę, poddadzą się, wbrew własnym ocenom sensu istnienia tych funduszy.

\section{Podsumowanie}

W dobie pieniądza fiducjarnego, uporczywie niskich stóp procentowych i głębokiej alienacji rynku kapitałowego względem realnej gospodarki, otwarte fundusze emerytalne (w tym także SFIO wraz PPK), to nic innego jak gigantyczna piramida finansowa, o dużej żywotności ze względu na masowość członkostwa i prawny przymus wnoszenia składek oraz odległy termin wypłaty świadczeń.

Forsując prywatyzację emerytur, polskie rządy, niezależnie od opcji politycznej i przedwyborczych deklaracji programowych, świadomie lub nie, realizują ekspansywną strategię globalnych korporacji, dla których przecież większość mediów, polityków i ludzi nauki jest niczym więcej niż chwilowo użytecznym (a mimo to, w istocie pogardzanym) narzędziem do uzyskiwania swych egoistycznych celów. Korporatokraci nie zostali wybrani $w$ demokratycznych wyborach, nie odpowiadaja przed nikim, za to doskonale wiedza, jak podporzadkować sobie polityków, media, środowiska naukowe (Perkins, 2007). Na ich potrzeby pracują wybitni akademicy (w tym nobliści), którzy podobnie jak dawni poszukiwacze kamienia filozoficznego, czy konstruktorzy perpetuum mobile - ustawicznie eksperymentują tworząc rzekomo niezawodne i wysoce rentowne modele inwestowania w produkty finansowe coraz to nowszych generacji.

Mając na uwadze wydarzenia $\mathrm{z}$ lat 2008-2009, państwo nie powinno ulegać lobbystom z rynku kapitałowego, ani wywierć nacisku na pracodawców, promując komercyjne produkty emerytalne obarczone wysokim ryzykiem. W sprawach dotyczących wielomilionowych grup społecznych rząd powinien dążyć do uzyskania rzeczywistego (a nie czysto formalnego) konsensusu społecznego; w żadnym wypadku stoickiej postawy obywateli wobec reformy emerytalnej nie należy mylić ze społeczną akceptacją, której skutkiem może być - niezamierzone, lecz realne - masowe wywłaszczenie polskich rodzin.

Polacy, zarówno zamożniejsi, jak i średnio sytuowani starali się bowiem ustabilizować swoją sytuację bytową, nabywając domy i mieszkania na własność; $\mathrm{z}$ badania przeprowadzonego przez NBP wynika, że nieruchomości stanowiły w $2016 \mathrm{r}$. aż 91,6\% ich majątku netto (NBP, 2017a, s. 6). Emeryci, postawieni wobec alternatywy: utrzymać własność kosztem drastycznych ograniczeń własnej konsumpcji, czy skorzystać z odwróconej hipoteki, przekażą instytucjom finansowym, to co najcenniejsze w ich dorobku życiowym - nieruchomości i ziemię, na której zbudowali swoje domy. Jeśli proces wywłaszczenia emerytów będzie miał wymiar masowy i będzie przebiegał żywiołowo, może przynieść dramatyczne następstwa nie tylko w wymiarze indywidualnym, ale także społecznym. W polskim systemie prawnym brakuje bowiem rozwiązań, które skutecznie zapobiegłyby nadużyciom ze strony grup zarządzających odwróconą hipoteką i innymi ryzykownymi produktami finansowymi.

„Program Budowy Kapitału” - stanowiący integralną część „Strategii na Rzecz Odpowiedzialnego Rozwoju" - nie w pełni wszedł w życie, zarówno z uwagi na brak decyzji w sprawie OFE i dalece odbiegające od oczekiwań wyniki PPK, ale także konieczność działań osłonowych w obliczu kryzysu wywołanego Pandemią COVID-19. W tych okolicznościach, ogromnej wartości aktywa zabezpieczające główne ryzyka 
socjalne (portfele OFE i FRD oraz środki Funduszu Pracy skąd wypłacane są ,zachęty” dla członków PPK) mogłyby ułatwić przywrócenie - w niezbyt odległej przyszłości klasycznej emerytury.

\section{Bibliografia}

Averting the old age crisis: policies to protect the old and promote growth (1994), World Bank Report No 13584, Washington D. C.

Barton D., Wiseman M. (2014), Focusing capital on the long term, "Harvard Business Review", January-February, hbr.org., dostęp 11. 10.2014.

Chomsky N. (2004), Na lewo od ściany, https://www.polityka.pl/tygodnikpolityka/spoleczenstwo/ 11062,1,na-lewo-od-sciany.read, dostęp 24.04.2019.

Dembinsky P. H. (2012), Finanse po zawale. Od euforii finansowej do gospodarczego ładu.

Wydawnictwo Studio Emka, Warszawa.

International Monetary Fund, World Economic Outlook, September 2006, http://www.imf.org/external /pubs/ft/weo/2006/02/pdf/weo0906.pdf, dostęp 02.09.2014.

Jończyk J. (2001), Prawo zabezpieczenia społecznego. Ubezpieczenia społeczne i zdrowotne, bezrobocie i pomoc społeczna, Kantor Wydawniczy Zakamycze, Zakamycze.

Kempa M. (2010), Wpływ OFE na saldo Funduszu Emerytalnego, MF Working Paper Series Nr 07-2010, Warszawa.

Klein N. (2010), Milton Friedman did not save Chile, "The Guardian", 3 March.

Kobosko M. (2012), Obama pogoni bankierów, wywiad Michała Kobosko ze Zbigniewem Brzezińskim „Wprost” z dnia 27 maja.

Konwencja Nr 102 Międzynarodowej Organizacji Pracy dotycząca minimalnych norm zabezpieczenia społecznego (Dz. U. z 1959 r. Nr 39, poz. 240).

Łaski K. (2003), O nonsensach polskiej reformy emerytalnej [w:] Polska po przejściach. Barometr społeczno-ekonomiczny 2001-2003 (red.) M. Deniszczuk i J. Supińska, Stowarzyszenie Studiów i Inicjatyw Społecznych, Warszawa.

Ministerstwo Finansów (2019), Wieloletni plan finansowy Państwa 2019-2022.

Myers, S. C. (1984). The capital structure puzzle. The Journal of Finance, 39, (3), 574-592.

Myers, S. C., \& Mayful, N. S. (1984). Corporate Financing and Investment Decisions When Firms Have Information Investors Do Not Have. Journal of Financial Economics, 13, 187-222.

NBP (2017), Rola emisji akcji w finansowaniu inwestycji przedsiębiorstw, Warszawa.

NBP (2017a), Zasobność gospodarstw domowych w Polsce. Raport z badania 2016 r. Warszawa. NBP (2019), Bilans Płatniczy Rzeczypospolitej Polskiej za IV kwartał 2018 r., Warszawa.

OECD (2019), Launch of the OECD Pensions Outlook 2018. https://read.oecdilibrary.org/finance-and-investment/oecd-pensions-outlook-2018_pens_outlook-2018-en\#page21.

Oręziak L. (2019), Rząd chce sprzedać nasze emerytury banksterom. Mało kto rozumie jakie to zagrożenie, https://oko.press/prof-oreziak-rzad-chce-sprzedac-nasze-emerytury-banksterom-malokto-rozumie-jakie-to-zagrozenie/, dostęp 15.06.2019.

Pernet M. (2019), Giełda to nie bank, ryzyko jest zawsze, „Parkiet” 14.06.

Perkins J. (2007), wypowiedź dla "Democracy Now” 05.06.2007, http://wezwaniedoprawdy.pl.tl/ Globalny-spisek.htm, dostęp 06.09.2015

Krugman P. (2012), Paul Krugman o przyszłości światowej gospodarki, streszczenie wywiadu dla New York Timesa autorstwa Agnieszki Mitraszewskiej, „Gazeta Wyborcza” z 27.02.

Sumatra G. (2005), Bad Management Theories Are Destroying Good Management Practices, Academy of Management Learning and Education t. 4 No 1.

Ustawa z 25 marca 2011 r. o zmianie niektórych ustaw związanych z funkcjonowaniem systemu ubezpieczeń społecznych (Dz. U. $2011 \mathrm{Nr} 75$ poz. 398).

Ustawa z dnia 13 października 1998 r. o systemie ubezpieczeń społecznych (Dz. U. 2016, poz. 963, z późn. zm.) 
Ustawa z dnia 6 grudnia 2013 r. o zmianie niektórych ustaw w związku z określeniem zasad wypłaty emerytur ze środków zgromadzonych w otwartych funduszach emerytalnych (Dz. U. 2013, poz. 1717).

Uzasadnienie do projektu ustawy z dnia 27 maja 2019 r. o zmianie niektórych ustaw w związku z przeniesieniem środków z otwartych funduszy emerytalnych na indywidualne konta emerytalne. Williamson J. B. (2004), A Short History of the Washington Consensus, Barcelona.

World Bank (2019) datatopics.worldbank.org/world-development-indicators/themes/states-andmarkets.html, dostęp 15.06.2019.

McKinsey (2012), Winning the \$ 30 trillion decathlon. Going for gold in emerging markets, Designed by McKinsey Publishing, Copyright (C) McKinsey \& Company, August.

World Bank (2019), Market capitalization of listed domestic companies (\% of GDP), https://data.worldbank.org/indicator/CM.MKT.LCAP.GD.ZS, dostęp 16.06.2019.

Zakład Ubezpieczeń Społecznych (2019), Informacja o świadczeniach pieniężnych z Funduszu Ubezpieczeń Społecznych oraz niektórych świadczeniach z zabezpieczenia społecznego, IV kwartał 2018/ okres I-XII 2018, https://www.zus.pl/documents/10182/167627/ Biuletyn_WOJ_K4_2018/3e549502-2692-7c36-804f-943a2845833e, dostęp 17.06.2019.

Żyżyński J. (2013), OFE - sztuka iluzji, „Nasz Dziennik” 24 maja, Nr 120 (4659).

\section{Summary}

Privatization of retirement funds in Poland began in 1999, when the defined benefits system was replaced by a defined contributions system, which led to the gradual cancelation of nearly all entitlements of employees. The partition of retirement contributions between the Open Retirement Fund (OFE) and the state-operated Social Security system (ZUS) has generated an enormous debt of the public sector (on the order of 300 billion PLN) and servicing of this debt has had devastating consequences for the state budget. Due to the pressure of the excessive deficit procedure imposed on Poland by the European Union, a process of phasing out the OFE scheme was initiated in order to improve the financial standing of the Polish general government sector, which has been achieved. However - in consequence - the introduced changes could have led to cancellation of the entire OFE program within several years. This has been prevented by the Program of Capital Building, which strengthens the capital market but carries significant risks of poverty and expropriation of persons who entered the labor market in 1990 or later. Privatization of assets in the OFE system makes the strengthening of the public Social Security system impossible; the financial burden of compulsory participation in the creation of the retirement capital market, imposed on small and medium enterprises, can adversely affect their financial standing and weaken the potential for development of the real economy in Poland.

Key words: open retirement funds, capital market, employee capital plans, social risks.

\section{JEL Codes: H55, H75}

Informacja o autorze:

prof. dr hab. Grażyna Ancyparowicz

Narodowy Bank Polski, Rada Polityki Pieniężnej

Górnośląska Wyższa Szkoła Handlowa

im. Wojciecha Korfantego w Katowicach

e-mail: sekretariat.rpp@nbp.p1

ORCID: 0000-0003-0196-78 